\title{
Effect of ferrous iron on the settling properties of granular sludge in a UASB reactor
}

\author{
A. Vlyssides, E. M. Barampouti, S. Mai \& A. Moutsatsou \\ National Technical University of Athens, \\ School of Chemical Engineering, Athens, Greece
}

\begin{abstract}
The effect of ferrous ion addition on the settling properties of the granules in an upflow anaerobic sludge blanket (UASB) reactor was investigated. A UASB reactor $\left(35^{\circ} \mathrm{C} ; \mathrm{pH}=7\right)$ was operated for 3 months at a 20 -h hydraulic retention time (HRT) at organic load from 2,0 to $20,0 \mathrm{gCOD} \mathrm{L}^{-1} \cdot \mathrm{d}^{-1}$. Ferrous iron as $\mathrm{FeSO}_{4} \cdot 7 \mathrm{H}_{2} \mathrm{O}$ was fed to the reactor in a range of load from 0,03 to $0,28 \mathrm{~g}$ $\mathrm{Fe}^{+2 .} \mathrm{L}^{-1} \cdot \mathrm{d}^{-1}$. After steady state conditions were achieved, the settling properties of granular sludge from the anaerobic sludge bed reactor were determined by using a novel upflow velocity test. From the results, it was concluded that iron promoted granulation. The U10\% (10\% of sludge washed out by applying upflow velocity $\mathrm{U} 10 \%$ ) was increased from $0,23 \mathrm{~m} \cdot \mathrm{h}^{-1}$ to $13,21 \mathrm{~m} \cdot \mathrm{h}^{-1}$, while U30\% from $0,87 \mathrm{~m} \cdot \mathrm{h}^{-1}$ to $29,11 \mathrm{~m} \cdot \mathrm{h}^{-1}$ and $\mathrm{U} 60 \%$ from $6,63 \mathrm{~m} \cdot \mathrm{h}^{-1}$ to $49,82 \mathrm{~m} \cdot \mathrm{h}^{-1}$. Keywords: UASB, granulation, ferrous iron, settling properties.
\end{abstract}

\section{Introduction}

The concept of the upflow anaerobic sludge blanket (UASB) reactor was developed in 1970s. Today the UASB reactor has become the most popular highrate reactor for anaerobic treatment of wastewater throughout the world $[1,2]$. The UASB reactor has been used increasingly in recent years to treat a variety of industrial waste and municipal waste. The treatment capacity of UASB reactors depends on the amount of active biomass retained, as well as the contact between biomass and wastewater. The biosolids inside the UASB reactor can be either in granular or flocculent form [3]. Retention of an adequate level of methanogenic bacteria in UASB reactors gives good performance in terms of chemical oxygen demand (COD) removal and methane yield $[1,4]$. 
Granulation is the process in which suspended biomass agglutinates to form discrete well-defined granules. Microbial granulation is a complex process, involving different trophic bacterial groups, and their physico-chemical and microbiological interactions [5]. Many factors contribute, in one form or another, to the granulation process $[6,7]$. Granulation may be initiated by bacterial adsorption and adhesion to inert matters, to inorganic precipitates [2, 8], and/or to each other through physico-chemical interactions and syntrophic associations [9]. These substances serve as initial precursors (carriers or nuclei) for further bacterial growth. These initial granules will grow continuously into compact mature granules, if favourable conditions pertaining to bacteria are maintained [10].

The granular form of the sludge offers various engineering advantages over the flocculent form, such as, the high solid retention time due to its excellent settling property, providing maximum microorganisms to space ratio, and application of higher loading rates as compared to UASB reactor with flocculent sludge. Hence, characteristics of the sludge developed are of vital importance for maximizing advantages of this reactor, and affecting the process economy [3].

Wastewater type rather than the loading rates and reactor design is reported to have strong influence on the bulk characteristics of sludge [11]. However, Liu and Tay [12] have stated that, the hydrodynamic conditions inside the reactor play crucial role in the formation of anaerobic granules. Applied loading rates are responsible for defining hydrodynamic conditions in the reactor. Based on the studies reported it could be said that, the characteristics of the sludge inside the reactor depend upon the operating conditions during primary start-up and granulation, apart from the characteristics of wastewater and inoculum used. For the same wastewater, the sludge characteristics differ with applied loading rates [3].

It has been shown that divalent metal ions, such as $\mathrm{Ca}^{2+}$ and $\mathrm{Fe}^{2+}$, enhance the granulation [8]. Divalent ions were reported to play an important role in microbial aggregation. Elemental analysis of granules pointed to the importance of inorganic precipitates, such as calcium phosphate, while other pointed to the importance of iron in non-chelated form or in chelated form [13]. It was found that extracellular polymers prefer to bind to multi-valent metals due to the formation of stable complexes [14].

The aim of this work was to investigate the influence of ferrous iron on the settling properties of UASB granular sludge under increasing loading rates.

\section{Materials and methods}

\subsection{Composition of feed}

Synthetic milk wastewater used in this study was prepared by diluting fresh milk. The COD of the wastewater ranged from $2000-20000 \mathrm{mg} \mathrm{L}^{-1}$. The total nitrogen and total phosphorous of the wastewater ranged from $100-1000 \mathrm{mg} \cdot \mathrm{L}^{-1}$ and $16-160 \mathrm{mg}^{-1}$ respectively. $\mathrm{pH}$ varied between $6,5-7,0$. 


\subsection{Reactor operating conditions}

A 20L UASB reactor was operated at $35^{\circ} \mathrm{C}$. Hydraulic retention time was $20 \mathrm{~h}$. The experimental schedule as far as COD load and ferrous ion load is concerned is shown in Figure 1. As it is obvious, the ratio of influent $\mathrm{COD} / \mathrm{Fe}^{2+}$ was maintained stable and equal to $0,014 \mathrm{~g}^{-1}$, which is found to be the optimum ratio (unpublished work).

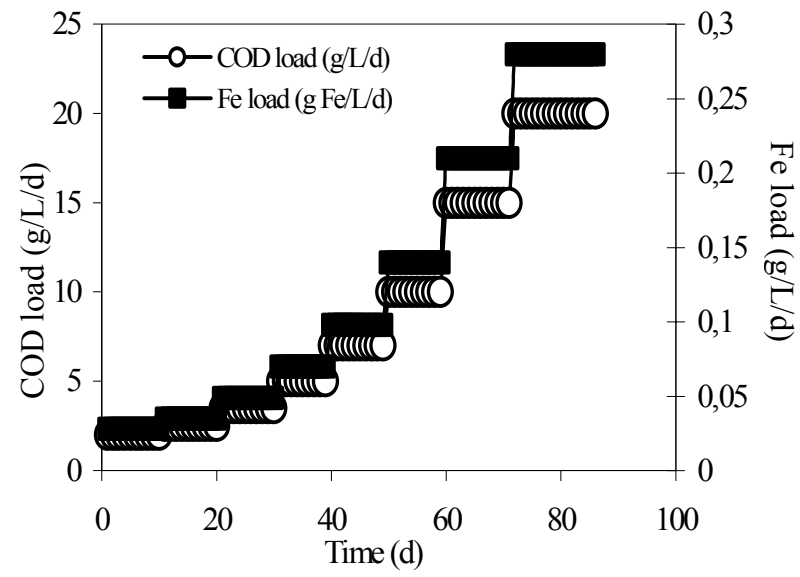

Figure 1: $\quad$ COD and iron experimental schedule.

During the reactor operation, the COD conversion, gas production and $\mathrm{pH}$ of the effluent were measured daily. For each loading rate, the performance data mentioned above were collected until steady state conditions were obtained. The steady state condition in the biological system implied that the daily changes in the biogas production and effluent COD were not more than $\pm 15 \%$ and $\pm 16 \%$ respectively. After steady state conditions were achieved, granules from the sludge bed of the UASB reactor were sampled for the determination of their settling characteristics. All analysis for pollution parameters were conducted in accordance with the standard methods.

\subsection{Settleability test}

A simple upflow velocity test to characterize settling properties of granular sludges from anaerobic sludge bed reactors was used [15].

\subsubsection{Apparatus}

A sludge sample from the sludge bed reactor was placed in a $60 \mathrm{~cm}$ long and $1 \mathrm{~cm}$ I.D. glass column and subjected to gradually increasing upflow velocities. A variable speed peristaltic pump pumped water through the test column in an upflow mode. Ten different flow velocities in ascending order, were maintained for 5 minutes each. Granules exited the glass column via an overflow port. The fraction of sludge exiting at each particular velocity was collected on filter paper and the dry weight of each fraction was determined. Percentage of suspended 
solids exiting the glass column plotted against upflow velocity gives the settling velocity profile of a particular sample. For the simultaneous filtration of granules that exited the glass column an 11,5 cm diameter Buchner funnel fitted with dried filter paper and connected to a vacuum flask was placed under the overflow port. A sketch of the apparatus is shown in Figure 2.

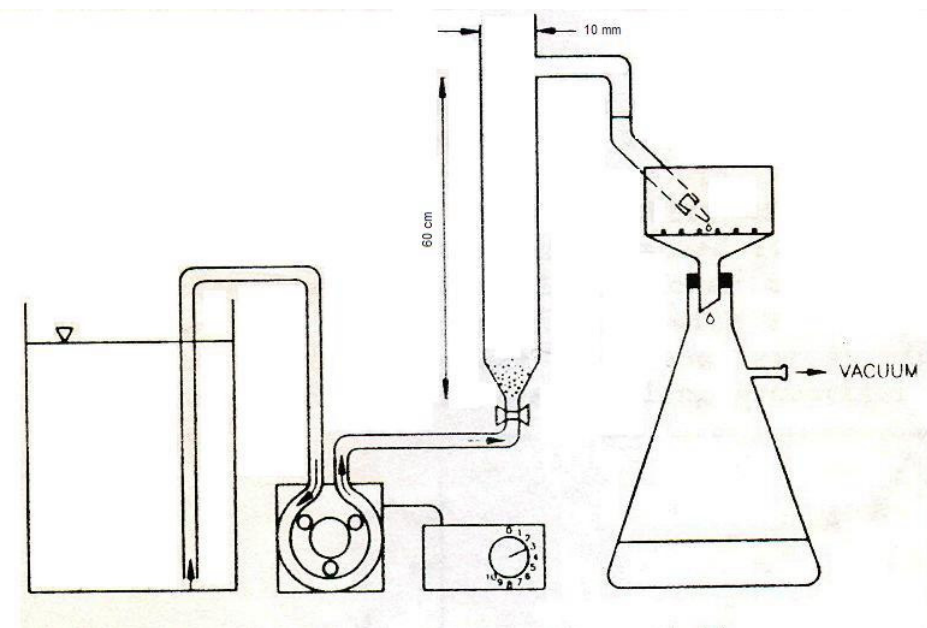

Figure 2: $\quad$ Test apparatus.

\subsubsection{Test procedure}

The glass column was half filled with tap water. Approximately $5 \mathrm{~mL}$ of concentrated sludge was transferred into the column while keeping the line connecting the bottom of the column with the pump clamped. The first filter paper was placed in the Buchner funnel, wetted and the vacuum started. The contents of the column were stirred to avoid the sludge moving in a slug, then the clump was removed and a pump was set to the desired velocity for 5 minutes. The column overflow was then switched over to a second filtration device while simultaneously increasing the flow velocity. This procedure (except for initial stirring) was repeated with subsequent higher flow velocities. Ten fractions were collected at upflow liquid velocities of 1,8, 2,2, 3,4, 5,1, 10,7, 16,8, 21,1, 30,9, $46,6,99,6 \mathrm{~m} \cdot \mathrm{h}^{-1}$ respectively. Granules still remaining in the column after the highest flow velocity were collected as the last fraction $\left(10^{+}\right)$. Next, total suspended solids values (TSS) of each fraction were determined.

\section{Results}

Plotting upflow velocity versus percent of TSS lost from the glass test device depicts a settling velocity profile of a particular sludge (Figures 3(a), 4(a)). In general this type of plot is rather descriptive, however it does give a basic understanding of the quality and nature of a particular sludge. 
(a)
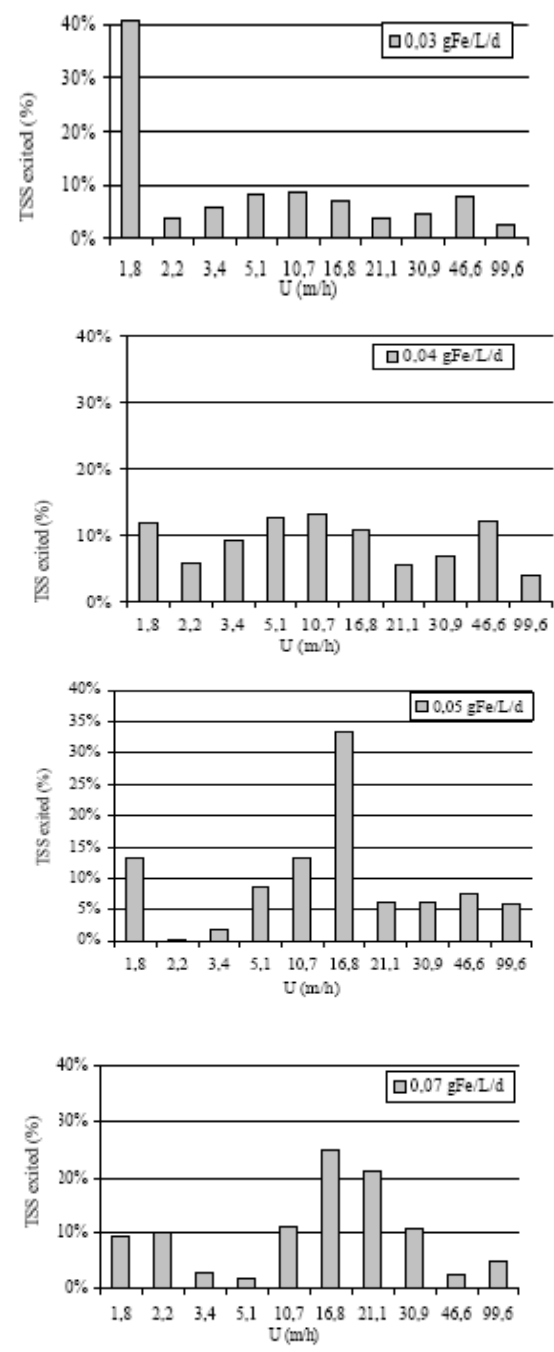

(b)
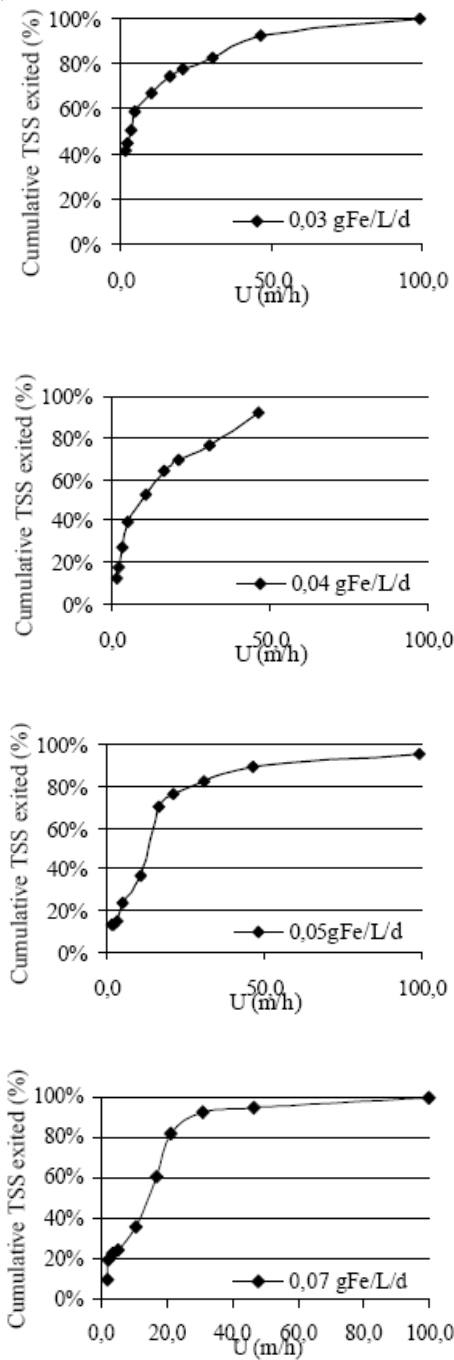

Figure 3: Upflow velocities profile (a) and cumulative solids loss plots (b) for $0,03,0,04,0,05,0,07 \mathrm{gFe} \cdot \mathrm{L}^{-1} \cdot \mathrm{d}^{-1}$ iron loads.

As one might expect, a poor settling sludge would have a large proportion of biomass exiting from the system at low upflow velocities, while a sludge with good settling properties would remain within the test system at much higher velocities. If the majority of sludge exited within a small range of upflow velocities, we characterize it as a homogeneous sludge with poor, moderate or good settling properties. 
166 Waste Management and the Environment III

(a)
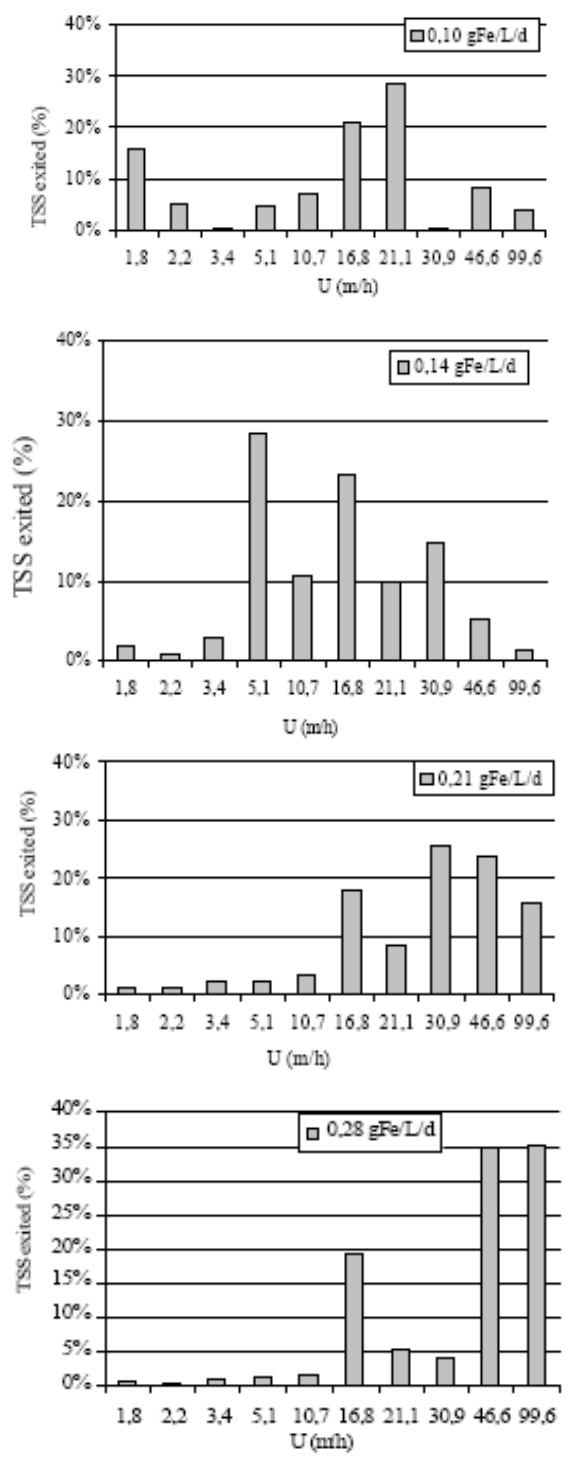

(b)
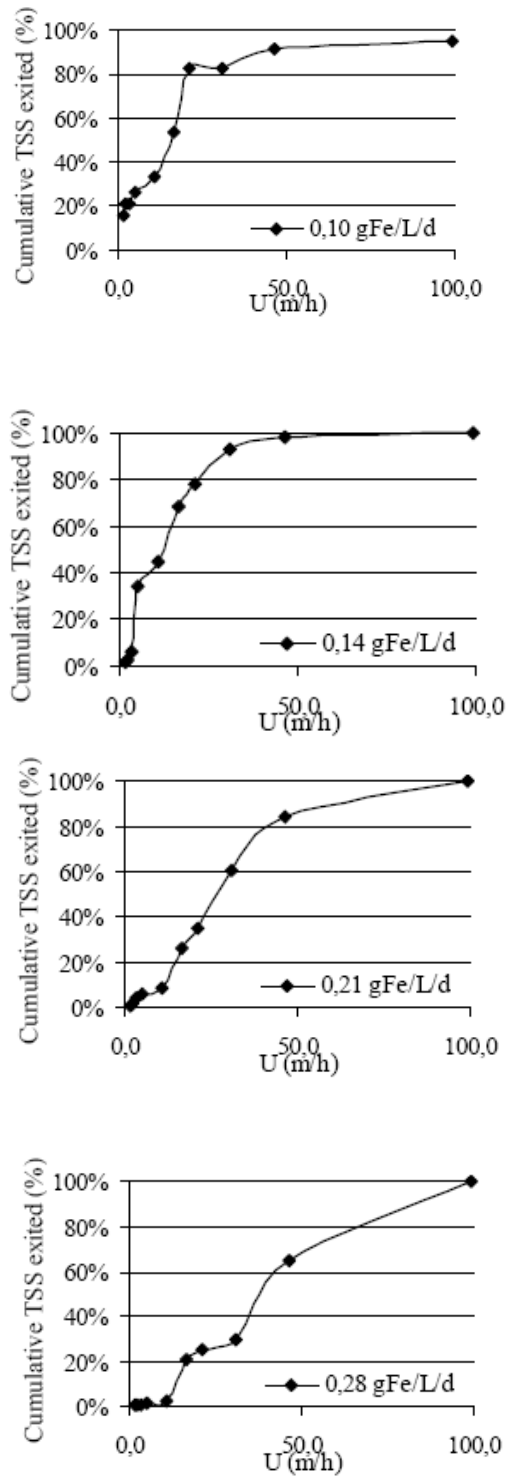

Figure 4: Upflow velocities profile (a) and cumulative solids loss plots (b) for $0,10,0,14,0,21,0,28 \mathrm{gFe} \cdot \mathrm{L}^{-1} \cdot \mathrm{d}^{-1}$ iron loads.

A plot of cumulative percent of TSS lost from the glass test device versus upflow velocity proved to be more informative and an easier way to interpret the results. Figures 3(b), 4(b) are the mean cumulative profiles for the five runs for each iron load applied. From the cumulative plots, the upflow velocities 
corresponding to wash out of $10 \%, 30 \%$ and $60 \%$ of the sludge (U10\%, U30\%, U60\%) were determined. The lower the upflow velocities U10\%, U30\% and $\mathrm{U} 60 \%$, the worse the settling characteristics of the sludge. Figure 5 represents the variations of $\mathrm{U} 10 \%, \mathrm{U} 30 \%$ and $\mathrm{U} 60 \%$ for each COD and iron load.

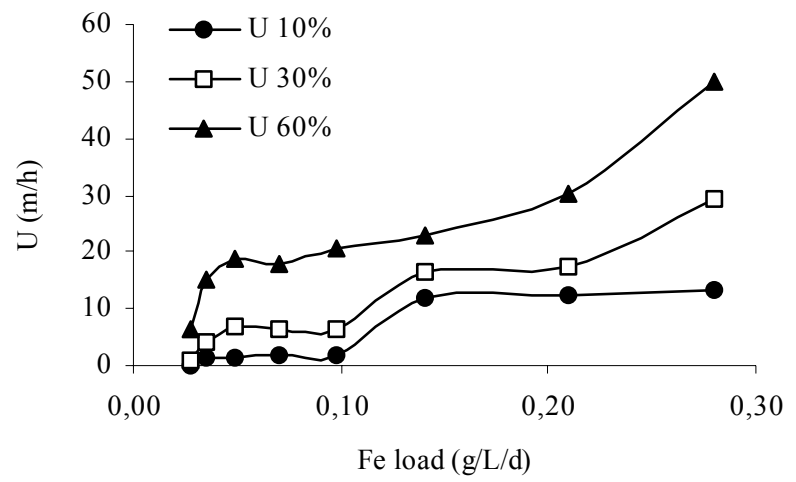

Figure 5: Variations of $\mathrm{U} 10 \%, \mathrm{U} 30 \%$ and $\mathrm{U} 60 \%$ for each COD and iron load.

$\mathrm{U} 10 \%$ increased from $0,23 \mathrm{~m} \cdot \mathrm{h}^{-1}$ to $13,21 \mathrm{~m} \cdot \mathrm{h}^{-1}, \mathrm{U} 30 \%$ from $0,87 \mathrm{~m} \cdot \mathrm{h}^{-1}$ to $29,11 \mathrm{~m} \cdot \mathrm{h}^{-1}$ and $\mathrm{U} 60 \%$ from $6,63 \mathrm{~m} \cdot \mathrm{h}^{-1}$ to $49,82 \mathrm{~m} \cdot \mathrm{h}^{-1}$.

\section{Conclusions}

According to Ghangrekar et al. [3] the settling characteristics of UASB anaerobic sludge deteriorate as the COD load increases. On the contrary, from the experiments described above, it is obvious that this is not the case. As the COD load was increased from 2,0 to $20,0 \mathrm{gCOD} \mathrm{L}^{-1} \cdot \mathrm{d}^{-1}$, the settling characteristics of sludge improved. This conclusion can be drawn from the values of the upflow velocities U10\%, U30\% and U60\%. Specifically, U10\% increased from $0,23 \mathrm{~m} \cdot \mathrm{h}^{-1}$ to $13,21 \mathrm{~m} \cdot \mathrm{h}^{-1}$, U30\% from $0,87 \mathrm{~m} \cdot \mathrm{h}^{-1}$ to $29,11 \mathrm{~m} \cdot \mathrm{h}^{-1}$ and $\mathrm{U} 60 \%$ from $6,63 \mathrm{~m} \cdot \mathrm{h}^{-1}$ to $49,82 \mathrm{~m} \cdot \mathrm{h}^{-1}$. This increase corresponds to a sludge bed with well-defined, larger granules which may resist to high hydraulic pressures. In other words, the addition of ferrous iron significantly contributes to the formation of granular sludge which a key function for the good operation of a UASB reactor.

It can also be noted that the characteristic upflow velocities increase more sharply as the ferrous iron addition gets greater. This increase may be attributed to the ferrous iron addition, which renders the granules larger.

\section{Acknowledgements}

This work was done under the operational Program for Educational and Vocational Training II (EPEAEK II) and particularly the Program 
HRAKLEITOS. The project is co-funded by the European Social Fund (75\%) and National Resources $(25 \%)$.

\section{References}

[1] Hulshoff Pol, L. W. The Phenomenon of Granulation of Anaerobic Sludge. Ph.D. Thesis, Wageningen Agricultural University, The Netherlands, 1989

[2] Lettinga, G., Man, A.D., ver der Last, A.R.M., Wiegant, W., van Knippenberg, K., Frijns, J. and van Buuren, J.C.L., Anaerobic treatment of domestic sewage and wastewater. Water Sci. Technol. 27, pp. 67-73, 1993.

[3] M.M. Ghangrekar, S.R. Asolekar and S.G. Joshi Characteristics of sludge developed under different loading conditions during UASB reactor startup and granulation, Water Research, Vol. 39, Issue 6, pp. 1123-1133, 2005

[4] Fang, H.H.P., Chui, H.K., Li, Y.Y. and Chen, T., Performance and granule characteristics of UASB process treating wastewater with hydrolyzed proteins. Water Sci. Technol. 30, pp. 55-63. 1994.

[5] Schmidt, J.E. and Ahring, B.K., Granular sludge formation in upflow anaerobic sludge blanket (UASB) reactors. Biotechnol. Bioeng. 49, pp. 229-246, 1996.

[6] De Zeeuw W. J., Acclimatization of anaerobic sludge for UASB reactor start-up. Ph.D. Thesis, Wageningen Agricultural University, The Netherlands, 1984

[7] Fang, H.H.P., Chui, H.K. and Li, Y.Y., Effect of degradation kinetics on the microstructure of anaerobic biogranules. Water. Sci. Technol. 32, pp.165-172, 1995.

[8] Mahoney, E.M., Varangu, L.K., Cairns, W.L., Kosaric, N. and Murray, R.G.E., The effect of calcium on microbial aggregation during UASB reactor start-up. Water Sci. Technol. 19, pp. 249-260, 1987.

[9] Dolfing, J., Griffioen van, A.R.W. and Zevenhuizen, L.P.T.M., Chemical and bacteriological composition of granular methanogenic sludge. Can. J. Microbiol. 31, pp. 744-750, 1985.

[10] Thaveesri, J., Daffonchio, D., Liessens, B., Vandemeren, P. and Verstraete, W., Granulation and sludge bed stability in upflow anaerobic sludge bed reactors in relation to surface themodynamics. Appl. Environ. Microbiol. 61, pp. 3681-3686, 1995.

[11] Batstone and Keller, 2001 D.J. Batstone and J. Keller, Variation of bulk properties of anaerobic granules with wastewater type, Water Res. 35 (7), pp. 1723-1729, 2001

[12] Liu and Tay, $2002 \mathrm{Yu}$. Liu and J.-H. Tay, The essential role of hydrodynamic shear force in the formation of biofilm and granular sludge, Water Res. 36, pp. 1653-1665, 2002 
[13] Oleszkiewicz, J. A.; Romanek, A. Granulation in anaerobic sludge bed reactors treating food industry wastes. Biological Wastes, 27(3), 217-35, 1989.

[14] Rudd, T., Sterritt, R. and Lester, J., Complexation of heavy metals by extracellular polymers in the activated sludge process. J. Water. Poll. Contam. Fed. 56, pp. 1260-1268, 1984.

[15] Andras E., Kennedy K.J. and Richardson D.A., Test for characterizing settleability of anaerobic sludge, Environmental Technology letters, Vol.10, pp.463-470, 1989. 